\title{
NOTES ON DICTYOLATHYS MACULATA BANKS
}

(ARANEÆ: DICTYNIDÆ)

\author{
By Elizabeth B. Bryant
}

Museum of Comparative Zoölogy, Cambridge, Mass.

Recently in examining some material from Raleigh, North Carolina, collected in January 1941, two females were found described as Dictyolathys maculata Banks. This genus, erected by Banks in 1900, was based on females from Mobile, Alabama, and Meridian, Mississippi, and was separated from Lathys by the strongly procurved anterior eye row.

In 1903, Simon, who had never seen a specimen, placed the genus as a synonym of Lathys and was followed by Emerton, in 1913. He described and figured the male from specimens collected May 1, 1912 at Lakehurst, New Jersey. At the end of the description, Emerton says, "In the original description of Dictyolathys maculata, Banks says that the front middle eyes can be indistinctly seen but I have not been able to find them in the Lakehurst specimens nor in the (Banks) type specimen from Alabama. They appear to have only six eyes in two groups as in Scotolathys pallida."

Today with the sharp light from a condenser, the small anterior median eyes seen by Banks can be distinctly placed both in the type and the specimens used by Emerton, as well as in the recent material from Raleigh, so that the Banks genus Dictyolathys can no longer be considered a synonym either of Lathys or Scotolathys.

For the benefit of those who do not have ready access to the original description of Dictyolathys Banks, I quote verbatim as follows:

"Much like Dictyna, but apparently six-eyed, three in a group each side but the A.M.E. are present, although very small, and situated close to and a little higher than the A.S.E. Head not much elevated; legs of moderate length, no spines, but very hairy; accessory spinning organs like Dictyna."

A more detailed description of the genus can now be writ- 
ten to include other characters not used by Banks in the original description.

\section{Genus Dictyolathys Banks}

Proc. Philadelphia Acad., 1900, p. 534.

Cephalothorax moderately high, no thoracic groove; eight eyes, lateral eyes on a low tubercle, a.m.e. very small on the posterior slope of the tubercle, widely separated, so that the anterior row of eyes is strongly procurved, posterior row slightly procurved, p.l.e. largest of the eight; clypeus equals a radius of a.l.e.; labium triangular, as long as wide; sternum convex, almost as wide as long, ending in a lobe between fourth coxæ; legs varying little in length, fourth pair longest, no spines, dorsal row of trichobothria on fourth tibia; calamistrum confined to basal half of fourth metatarsus.

Dictyolathys is separated from Lathys by the strongly procurved anterior eye row, and the p.l.e. larger than the p.m.e., and from Scotolathys by the presence of small a.m.e. and the large p.l.e.

The genus Lathys Simon, 1884, was based on the species humilis Blackwall, common to northern Europe. This has eight eyes, with the anterior row straight, eyes contiguous, a.m.e. very small, posterior row slightly procurved, eyes equal and usually equidistant.

The genus Scotolathys Simon, 1884, was erected for a species, ( simplex) from Algiers, with but six eyes, the a.l.e. the largest of the eight. In both Les Histoire Naturelle des Araignées, 1903, 2, p. 977 and Les Arachnides de France, 1914, 6, p. 62, Simon has placed Lathys heterophthalma Kulczynski, 1891, in the genus Scotolathys but states that the a.m.e. almost obliterated. No specimens of this species are in the museum collection; but in the original description, " + Oculorum; series posterior paullo procurva, oculi magni, inter se subæquales et spatiis parum inæqualibus, circiter radium æquantibus remoti; series anterior subrecta, oculi valde inæquales, mediorum diameter radio lateralium minor, oculi laterales posticis subæquales, medii inter se late (plus quam diametro sua) distantes, lateralibus valde approximate." Having regard to this and the figures, it would seem that Kulczynski was correct in placing the species in the genus Lathys. 
Dictyolathys maculata Banks

Figure 1

Proc. Philadelphia Acad., 1900, p. 534.

Female. Length, $1.5 \mathrm{~mm}$.

Cephalothorax moderately convex, cephalic portion level, with a median row of very long bristles from near the posterior margin to eyes, thoracic portion falls rapidly to posterior margin; eyes in two groups that do not cover the anterior margin, anterior row strongly procurved, lateral eyes on a tubercle, a.l.e. separated by a diameter, a.m.e. very small, on posterior slope of tubercle, posterior row procurved, p.l.e. largest of the eight,
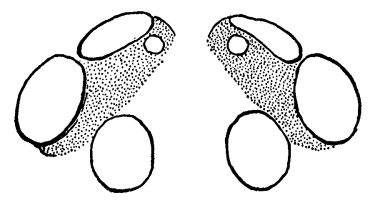

$A$

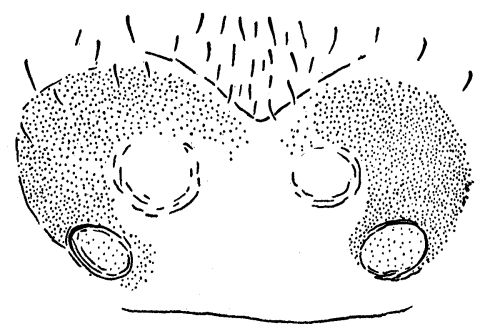

B

FIG. 1. Dictyolathys maculata Banks. A, eyes; B, epigynum.

separated from a.l.e. by a line and from p.m.e. by less than a radius, p.m.e. separated by about a diameter; quadrangle of median eyes much narrower in front and as high as wide behind; clypeus as high as radius of a.l.e.; mandibles small, verticle; labium triangular, with tip black, not fused to sternum; maxilla inclined over labium with tips almost touching; sternum pale, strongly convex, only slightly longer than wide, ending in a lobe between IV coxæ, IV coxæ widely separated; abdomen oval, pale, with a small median basal black spot, followed by five pairs of diagonal black spots, sides with black streaks, venter pale; legs, pale, relatively short, varying little in length, but the IV pair longest, no spines, a dorsal row of trichobothria on IV tibia; calamistrum of curved bristles, less than the diameter of the joint in length, on basal half of IV metatarsus; epigynum large for the size of the spider, chitinized area wider than long, with openings widely separated, and a pale depressed area just anterior to openings. 
Dictyolathys maculata Banks has been reported by Bishop and Crosby in 1926, from Madison and Raleigh, North Carolina and by Gertsch and Mulaik in 1940, from Houston, Harris Co., Texas.

Material in the Museum of Compartive Zoölogy Collection: Holotype Ala.; Mobile, Banks Coll.

2 ô N. J.; Lakehurst, 1 May 1912, Emerton Coll.

2 i N. C.; Raleigh, oak woods, 23 January 1941, (Wray).

In 1904, Banks described Dictyolathys californica from Palo Alto, California, also from a female. Unfortunately, this specimen cannot be found in the museum collection, but from the description and the figures, it probably does not belong to the genus Dictyolathys since the small a.m.e. are only a diameter apart; the anterior row is almost straight as in Lathys and the other eyes are subequal.

\section{REFERENCES}

Banks, Nathan. 1900. Some Arachnida from Alabama. Proc. Philadelphia Acad., pp. 529-543.

- 1904. Some Arachnida from California. Proc. California Acad., 3rd ser., 3, pp. 331-369, pls. 38-41.

Chyzer et Kulczynski. 1892. Araneæ Hungariæ, vol. 1, p. 161.

Emerton, J. H. 1913. New and Rare Spiders from within fifty miles of New York City. Bull. American Mus. Nat. Hist., 32, pp. 255-260, pl. 48.

Simon, Eugene. 1913. Histoire Naturelle des Araignées, 2, p. 977.

- 1914. Arachnides de France, 6, p. 62.

Bishop, S. C. and Crosby, C. R. 1926. Notes on the Spiders of the Southeastern United States with Descriptions of New Species. Jour. Elisha Mitchell Sci. Soc., 41, pp. 165-212, pls. 20-25. 

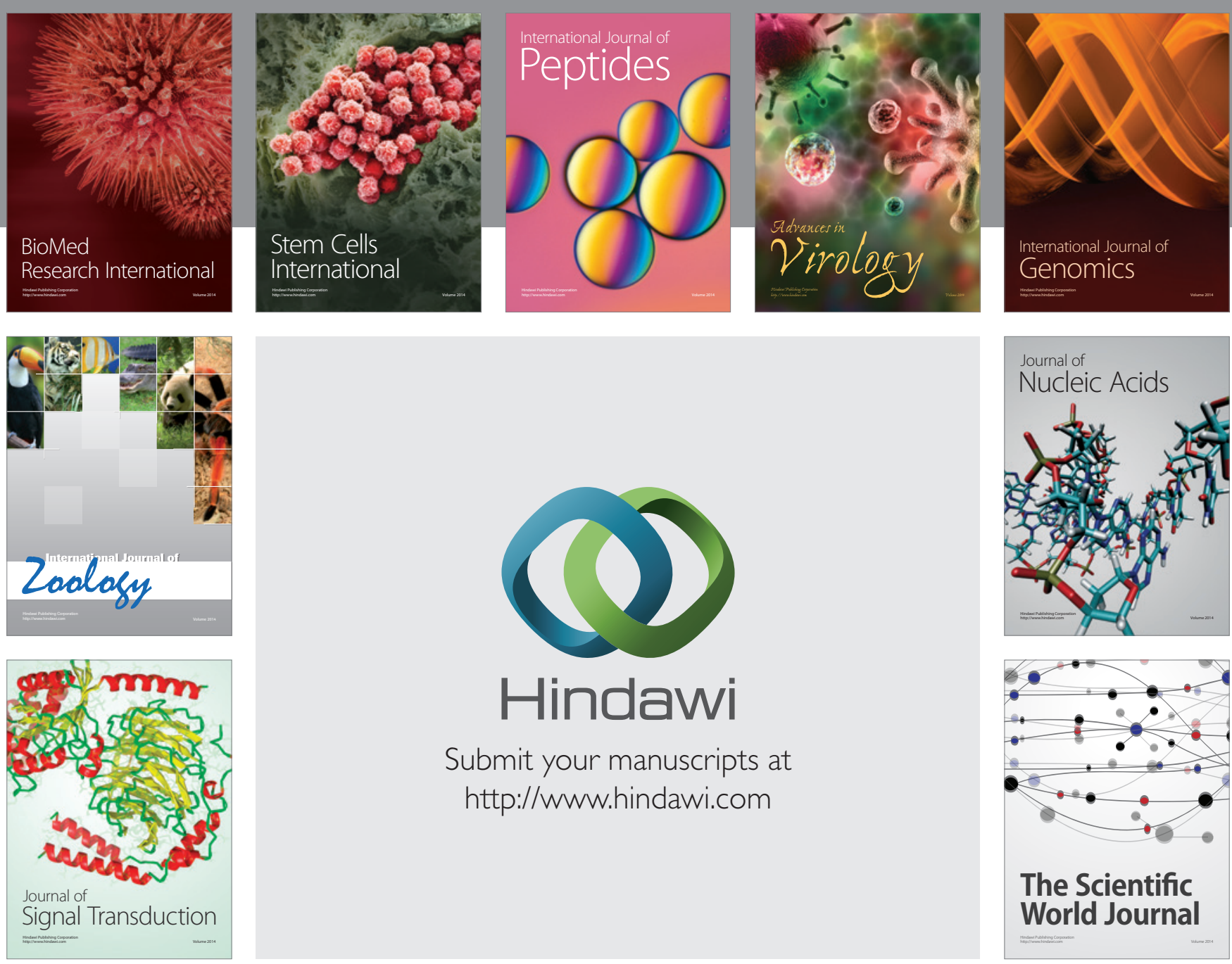

Submit your manuscripts at

http://www.hindawi.com
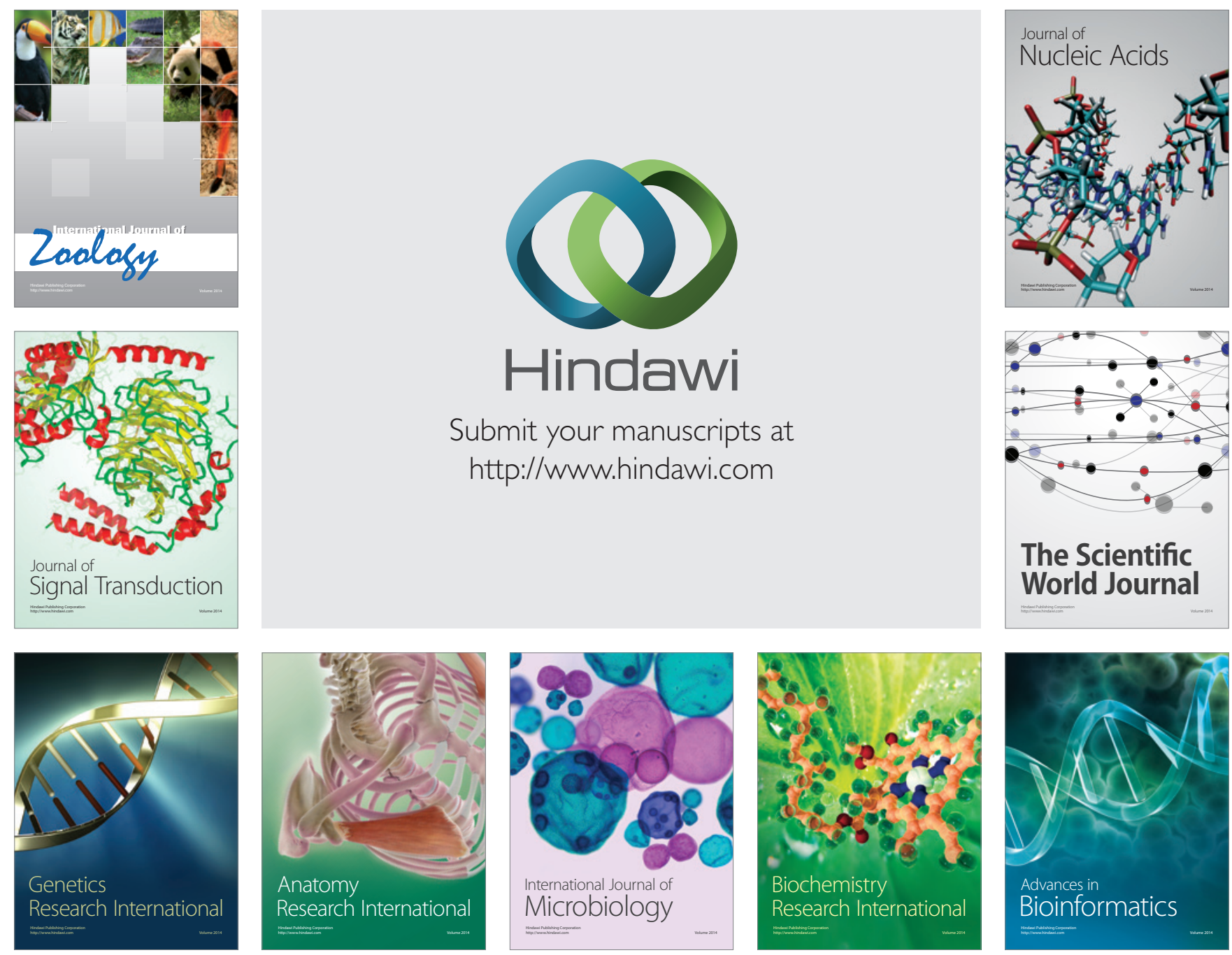

The Scientific World Journal
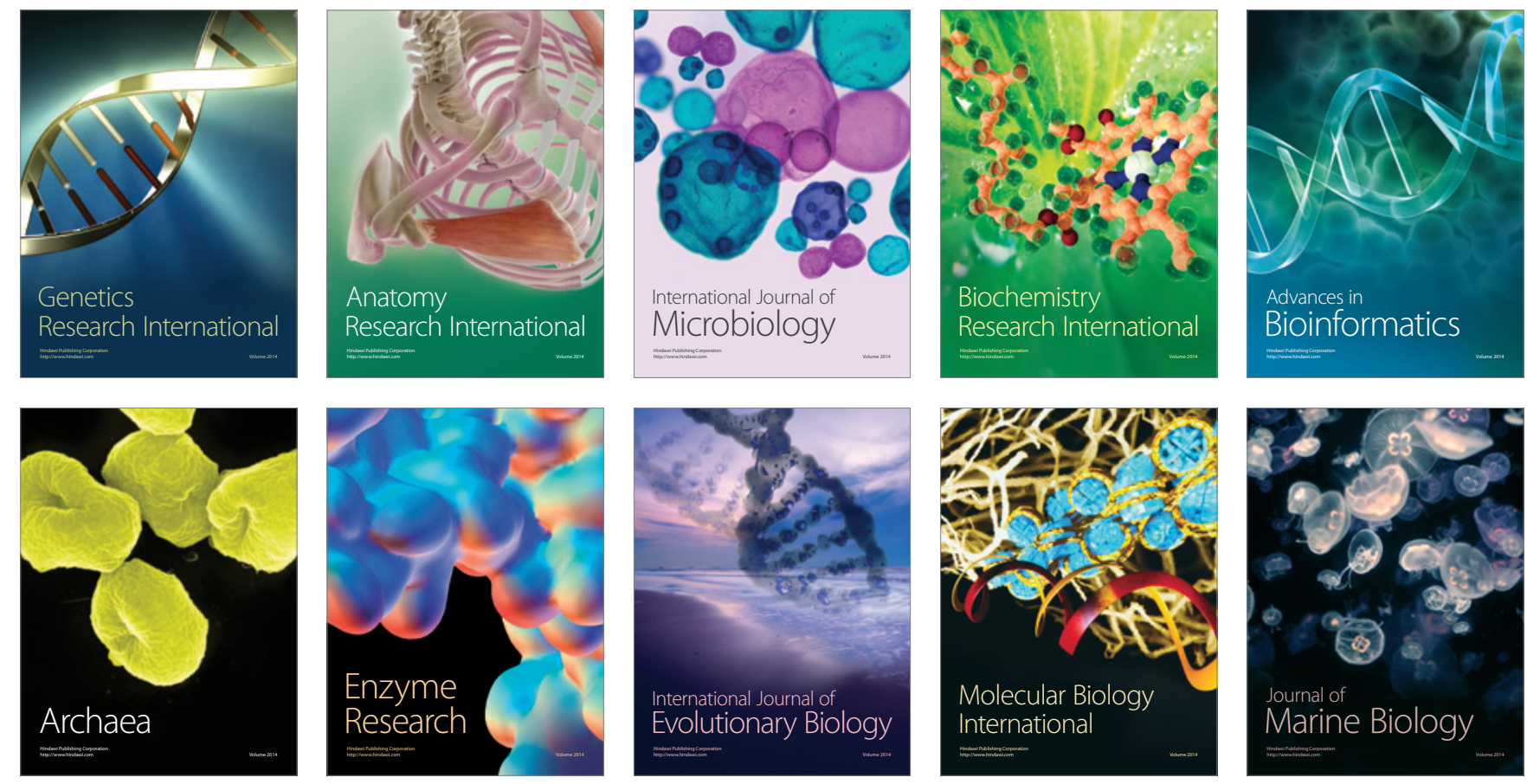